\title{
Detection of both vanA \& vanB genes in vanA phenotypes of Enterococci by Taq Man RT-PCR
}

\author{
Bahman Mirzaei ${ }^{1}$, Ryhane Babaei ${ }^{2}$, Akbar Pour Dadash Asiabar ${ }^{3}$, Zakaria Bameri $^{4}$ \\ ${ }^{1}$ Pasteur Institute of Iran, Tehran, Iran. \\ ${ }^{2}$ University of Medical Science, Qazvin, Iran. \\ ${ }^{3}$ Microbiology Laboratory, Dr. Shariati Hospital, Tehran, Iran. \\ ${ }^{4}$ Research Center for Infectious Disease and Tropical Medicine, \\ Zahedan University of Medical Science, Zahedan, Iran.
}

Submitted: November 20, 2013; Approved: June 6, 2014.

\begin{abstract}
Twenty seven isolates of vancomycin resistant Enterococci based on the disk diffusion and E- test have been screened; being found eight ( $0.3 \%$ ) clinical isolates of $v a n A \& v a n B$ through Taq Man Real Time PCR assay. This study shows the presence of both van $A$ \& vanB genotypes in vanA phenotypes clinical isolates in the three hospitals in Iran.
\end{abstract}

Key words: vanA \& vanB genotypes, vancomycin, Taq Man Real Time PCR, Enterococci.

Enterococci as an opportunistic microbiota are one of the most important microorganisms found in the environment. In some condition they can become pathogen, causing urinary tract infection (UTI), skin infections, respiratory infections, endocarditis and sepsis (Emaneini et al., 2008). This genus of bacteria due to various different of antibiotic resistance genes, intrinsically has shown resistance against some antibiotics including aminoglycosides, macrolids, $\beta$-lactams and semisyntetic penicillin's (Kacmaz et al., 2009). Following the first isolated vancomycin resistant enterococci (VREs) in 1980; these microorganisms have emerged as important nosocomial pathogens in worldwide (Japoni et al., 2009, Feizabadi et al., 2008). Many studies have mentioned that the resistance to vancomycin is complex process and needs to presence of multiple genes (Malathum et al., 2005, Kacmaz et al., 2009). According to the Malathum (2005), seven genes clusters were investigated in vancomycin resistance enterococci including: (van A, vanB, vancl, vanc2, vanD, vanE, and van $G$ ). Common resistance mechanism to glycopeptides such as vancomycin concerned with, dipeptide like termini (D-AlaD-Lac) encoded by vanA and vanB clusters which, prompt to low affinity for vancomycin (Malathum et al., 2005). Mobile genetic elements (transposons and plasmids), previously have been noticed as main resistance genes trans- ferring among Enterococci spp (Palladino et al., 2008, Emaneini et al., 2008, Japoni et al., 2009). Genes (vanA and $v a n B$ ) encoding dipeptide like termini are responsible for high or moderate level vancomycin resistance (Malathum et al., 2005, Palladino et al., 2006, Arbeur et al., 2008).

In this study, during 2011, one hundred eighty five strains of enterococci were isolated from clinical laboratories from three hospitals (Dr., Shariati, Sina, Masih Daneshvari) in Tehran, Iran. Isolated strains were identified using the conventional microbial tests according to the scheme utilized as previously described (Forbes et al., 1998, Louis et al., 2001). Following the incubation of inoculated isolates in Azid maltose agar culture medium (Himedia, India) at the $35^{\circ} \mathrm{C}$ for $24 \mathrm{~h}$, bacterial suspensions were prepared in sterile saline to obtain a turbidity of 0.5 MacFarland standard, equivalent to $1.5 \times 10^{8} \mathrm{cfu} / \mathrm{mL}$. Turbidity was measured by spectrophotometer instrument (Gensyse 10 UV spectrum, USA). Susceptibility testing for Enterococci isolates was performed by disk diffusion and E-test according to the clinical laboratory standard institute guideline (CLSI 2010). Disk diffusion method by utilizing disk containing $30 \mu \mathrm{g}$ vancomycin $\left(\mathrm{BD} \mathrm{BBL}^{\mathrm{TM}}\right.$ Sensi Disc $^{\mathrm{TM}}$ ) and E-test technology (AB BIODISK, Solna Sweden) as the recommended methods in CLSI 2010 were applied for detection of VREs strains. To carry out the tech-

Send correspondence to Z. Bameri. Research Zahedan University of Medical Science Booali Hospital, Zahedan, Iran. E-mail: zakariabameri@gmail.com. 
niques of disk diffusion and E-test Petri dishes with Mueller-Hinton (Merck, Germany) were applied. Bacteria were inoculated on the recommended media after dipped swabs in bacterial suspension, being implanted disks and E-test strips. Subsequently, plates were incubated in $35^{\circ} \mathrm{C}$ for $24 \mathrm{~h}$. Minimum inhibitory concentrations (MICs) breakpoints for vancomycin were determined by manufacturer's recommendation. Enterococcus faecalis ATTC 29212 and Enterococcus faecium BM4147 were used as sensitive and resistant strains, respectively. Both vanA \& vanB positive genotypes underlined. See Table 1.

After susceptibility testing (E-test), Enterococci isolates with MIC $\geq 32$ breakpoint were screened. Using a commercial kit (Roche, Diagnostics GmbH, Mannheim, Germany) genomic DNA from each VREs isolates was ex- tracted. Purified DNA was dissolved in $50 \mu \mathrm{L}$ distilled water. Quantity of extracted DNA was measured by NANODROP ${ }^{\circledR} N D-1000$ instrument (spectrophotometer 1000, USA) and adjusted to $500 \mathrm{ng} \cdot \mu \mathrm{L}^{-1}$.

Purified DNA was reconfirmed by polymerase chain reaction (PCR) by utilizing rrs gene (16s rRNA). Amplification protocol originally described by previously published study (Japoni et al., 2009). PCR was performed utilizing $5 \mu \mathrm{L}$ genomic DNA as template in total volume $25 \mu \mathrm{L}$ containing; $10 \mu \mathrm{L}$ master amplicon (Biolab, New England, UK), Forward primer (5'-GGATTAGATACCC TGGTGGTAGTCC-3') $1 \mu \mathrm{M}, \quad$ Reverse primer (5'-TCGTTGCGCACCTTAACCAAC-3') $1 \mu \mathrm{M}$ and $8 \mu \mathrm{L}$ mineral oil. PCR process was optimized with purified DNA

Table 1 - Phenotype and genotype characteristics in VREs strains.

\begin{tabular}{|c|c|c|c|c|c|}
\hline \multirow{2}{*}{$\begin{array}{l}\text { Enterococci } \\
\text { VREs }\end{array}$} & \multicolumn{2}{|c|}{ Phenotypes } & \multicolumn{3}{|c|}{ Genotypes } \\
\hline & Disc diffusion zone diameter & (MIC) $\mu \mathrm{g} / \mathrm{mL}$ & vanA gene & vanB gene & van $A \&$ van $B$ genes \\
\hline E. faecium & $0(\mathrm{R})$ & $>256 \mu \mathrm{g} / \mathrm{mL}$ & $P$ & $\mathrm{~N}$ & $\mathrm{~N}$ \\
\hline E. faecium & $0(\mathrm{R})$ & $256 \mu \mathrm{g} / \mathrm{mL}$ & $\mathrm{P}$ & $\mathrm{N}$ & $\mathrm{N}$ \\
\hline E. faecium & $1(\mathrm{R})$ & $256 \mu \mathrm{g} / \mathrm{mL}$ & $P$ & $\mathrm{~N}$ & $\mathrm{~N}$ \\
\hline E. faecium & $0(\mathrm{R})$ & $256 \mu \mathrm{g} / \mathrm{mL}$ & $P$ & $\mathrm{~N}$ & $\mathrm{~N}$ \\
\hline E. faecium & $0(\mathrm{R})$ & $256 \mu \mathrm{g} / \mathrm{mL}$ & $\mathrm{P}$ & $\mathrm{N}$ & $\mathrm{N}$ \\
\hline E. faecium & $8(\mathrm{R})$ & $196 \mu \mathrm{g} / \mathrm{mL}$ & $P$ & $\mathrm{~N}$ & $\mathrm{~N}$ \\
\hline E. faecium & $8(\mathrm{R})$ & $196 \mu \mathrm{g} / \mathrm{mL}$ & $\mathrm{P}$ & $\mathrm{N}$ & $\mathrm{N}$ \\
\hline E. faecium & $12(\mathrm{R})$ & $96 \mu \mathrm{g} / \mathrm{mL}$ & $\mathrm{N}$ & $P$ & $\mathrm{~N}$ \\
\hline$\underline{\text { E. faecium }}$ & $0(\mathrm{R})$ & $>256 \mu \mathrm{g} / \mathrm{mL}$ & $\mathrm{P}$ & $P$ & $\mathrm{P}$ \\
\hline E. faecium & $0(\mathrm{R})$ & $>256 \mu \mathrm{g} / \mathrm{mL}$ & $\mathrm{P}$ & $P$ & $\mathrm{P}$ \\
\hline E. faecium & $1(\mathrm{R})$ & $256 \mu \mathrm{g} / \mathrm{mL}$ & $\mathrm{P}$ & $\mathrm{P}$ & $\mathrm{P}$ \\
\hline E. faecalis & $0(\mathrm{R})$ & $>256 \mu \mathrm{g} / \mathrm{mL}$ & $\mathrm{P}$ & $\mathrm{P}$ & $\mathrm{N}$ \\
\hline E. faecalis & $0(\mathrm{R})$ & $256 \mu \mathrm{g} / \mathrm{mL}$ & $\mathrm{P}$ & $\mathrm{P}$ & $\mathrm{N}$ \\
\hline E. faecalis & $12(\mathrm{R})$ & $128 \mu \mathrm{g} / \mathrm{mL}$ & $\mathrm{P}$ & $\mathrm{P}$ & $\mathrm{N}$ \\
\hline E. faecalis & 11(R) & $128 \mu \mathrm{g} / \mathrm{mL}$ & $\mathrm{P}$ & $\mathrm{P}$ & $\mathrm{N}$ \\
\hline E. faecalis & $11(\mathrm{R})$ & $128 \mu \mathrm{g} / \mathrm{mL}$ & $\mathrm{P}$ & $\mathrm{P}$ & $\mathrm{N}$ \\
\hline E. faecalis & $14(\mathrm{R})$ & $64 \mu \mathrm{g} / \mathrm{mL}$ & $\mathrm{N}$ & $\mathrm{P}$ & $\mathrm{N}$ \\
\hline E. faecalis & $14(\mathrm{R})$ & $64 \mu \mathrm{g} / \mathrm{mL}$ & $\mathrm{N}$ & $\mathrm{P}$ & $\mathrm{N}$ \\
\hline E. faecalis & 14(R) & $32 \mu \mathrm{g} / \mathrm{mL}$ & $\mathrm{N}$ & $\mathrm{P}$ & $\mathrm{N}$ \\
\hline E. faecalis & $14(\mathrm{R})$ & $32 \mu \mathrm{g} / \mathrm{mL}$ & $\mathrm{N}$ & $P$ & $\mathrm{~N}$ \\
\hline E. faecalis & 14(R) & $32 \mu \mathrm{g} / \mathrm{mL}$ & $\mathrm{N}$ & $\mathrm{P}$ & $\mathrm{N}$ \\
\hline E. faecalis & $12(\mathrm{R})$ & $96 \mu \mathrm{g} / \mathrm{mL}$ & $\mathrm{N}$ & $\mathrm{P}$ & $\mathrm{N}$ \\
\hline$\underline{\text { E. faecalis }}$ & $8(\mathrm{R})$ & $196 \mu \mathrm{g} / \mathrm{mL}$ & $\mathrm{P}$ & $\mathrm{P}$ & $\mathrm{P}$ \\
\hline$\underline{\text { E. faecalis }}$ & $0(\mathrm{R})$ & $256 \mu \mathrm{g} / \mathrm{mL}$ & $\mathrm{P}$ & $\mathrm{P}$ & $\mathrm{P}$ \\
\hline E. faecalis & $0(\mathrm{R})$ & $>256 \mu \mathrm{g} / \mathrm{mL}$ & $\mathrm{P}$ & $P$ & $\mathrm{P}$ \\
\hline E. faecalis & $1(\mathrm{R})$ & $256 \mu \mathrm{g} / \mathrm{mL}$ & $P$ & $\mathrm{P}$ & $\mathrm{P}$ \\
\hline E. faecalis & $6(\mathrm{R})$ & $196 \mu \mathrm{g} / \mathrm{mL}$ & $\mathrm{P}$ & $\mathrm{P}$ & $\mathrm{P}$ \\
\hline
\end{tabular}

R, resistant; VREs, vancomycin resistant Enterococci; MIC, minimum inhibitory concentration; $\mu \mathrm{g} / \mathrm{mL}$, microgram per milliliter; P, positive; N, negative. 
of Enterococcus faecalis V583 and Enterococcus faecium BM4147 as positive genotypes. Amplification was performed on Gene Amp PCR system (Applied Biosystem, USA) using a program as follow: an initial cycle of denaturation $95{ }^{\circ} \mathrm{C}$ for $5 \mathrm{~min}$ followed by 35 cycles of $95{ }^{\circ} \mathrm{C}$ for $1 \mathrm{~min}, 50^{\circ} \mathrm{C}$ for $1 \mathrm{~min}$ and $72^{\circ} \mathrm{C}$ for $1 \mathrm{~min}$, with final extension (Japoni et al., 2009). Amplified products were visualized on $1.5 \%$ agarose gel (Max pure agarose, Spain) stained by etidium bromide by Gel logic 212 pro.

For precise and rapid detection of high and moderate vancomycin resistant Enterococci (vanA and vanB genes in this study), vancomycin resistance determinants van $A$ and $v a n B$ were targeted by Taq Man Real Time PCR assay. Determination of mentioned genes was performed using $\mathrm{ABI}$ 7500 USA instrument. (Figure 1). Specific primers and probes were designed as follow; reference vanA and vanB sequences representing each of van $A$ and vanB (vanB1/vanB2/vanB3) were assembled from the GenBank data base (http://www.ncbi.nlm.gov/GenBank). The utilized accession numbers were vanA (M97297) and vanB (U00456.1) respectively. Sequences were aligned using computer software beacon designer version 7. Sequence of designed primers and probes and Real Time PCR condition are listed in Table 2.
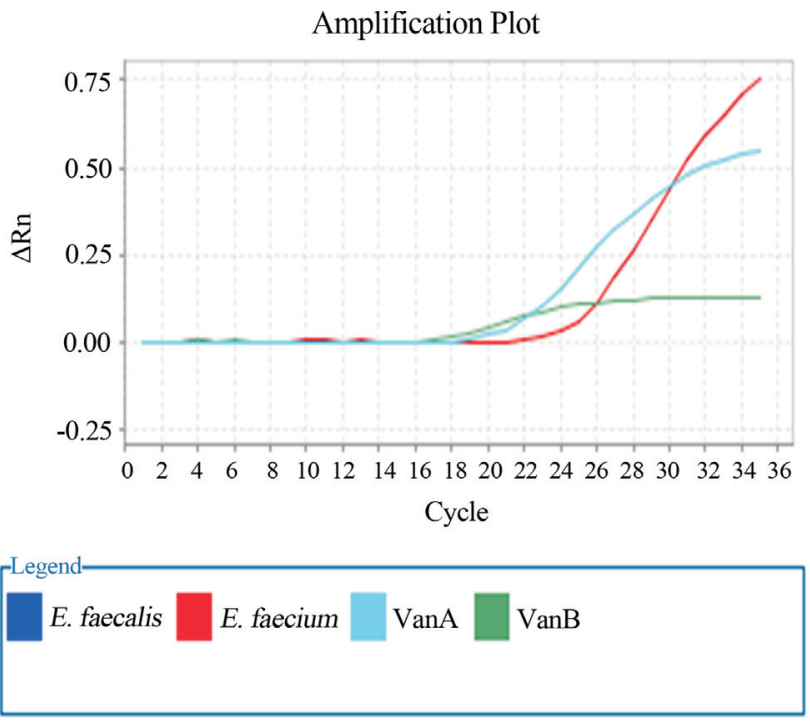

Figure 1 - Standard linear amplification plot for $v a n A \&$ vanB positive.
In this study statistical analyze was done by SPSS software version 16 by using Fisher exact test and $p<0.05$ was considered significant.

Out of 185 Enterococci isolates 27 (0.14\%) VREs strains consisting of 16/27 (0.59\%) Enterococcus faecalis and 11/27 (0.41\%) Enterococcus faecium were detected. Our study shows that Enterococcus faecalis and Enterococcus faecium were predominant isolates in VREs. Subsequently prevalence of vanA \& vanB from vanA phenotypes were 3/27 (0.11\%) Enterococcus faecium and 5/27 (0.18\%) Enterococcus faecalis. Giridhara (2009) reported that, since 1980 (first report of isolated VREs) colonization and related infections by VREs as main causative nosocomial infections agents were enhanced (Giridhara et al., 2009). Several Real Time PCR protocols have been developed for rapid and precise detection of resistance genes such as vancomycin resistance. According to the Mirzaei (2013) concentration of primer and probes, annealing, temperature, amplification cycle with pure and defined concentration of template DNA were carefully adjusted in order to optimize to Taq Man Real Time PCR assay (Mirzaei et al., 2013). Our optimized Taq Man Real Time PCR assay had $96 \%$ similarity of phenotypic methods such as E-test and disk diffusion methods for a description of VREs.

The results of Taq Man Real Time PCR assay disclosed the isolates with vanA positive gene were predominant. $\operatorname{Van} B$ were detected, while vanA observed in eight $(0.03 \%)$ high level resistant Enterococci. According to the Xiomara (2002) and Sharifi (2012) the phenotypic methods such as E-test are the convenient and useful methods for determining of minimum inhibitory concentration (MIC) for vancomycin in Enterococci (Xiomara et al., 2002, Sharifi et al., 2012). Our study affirmed mentioned studies and showed that Taq Man Real Time PCR assay is the useful methods for rapid and precise screening of VREs too. This method is more specific than traditional phenotypic methods for determination of both vanA and vanB genotypes in VREs phenotypes. Precise and rapid detection of vancomycin resistance genes lead to enhance the accuracy of VREs screening and consequently could help clinicians to timely administer appropriate antibiotics which may be life saving (Mirzaei et al., 2013). According to the some mentioned studies dissemination of VREs due to vanA and $v a n B$ genes in Iran has presented serious challenges for the

Table 2 - Sequence of designed primers and probes and Taq Man Real Time PCR assay condition.

\begin{tabular}{lcc}
\hline van primers & Forward $\left(5^{\prime}-3^{\prime}\right)$ & Reverse $\left(5^{\prime}-3^{\prime}\right)$ \\
\hline $\begin{array}{l}\text { vanA } \text { primer: } \\
\text { vanA } \text { probe }\end{array}$ & TGGAGCGACAGACATAACAGAT & ACACCTACGGGCGAGTTC \\
vanB primer: & \multicolumn{2}{c}{ JOE-TATTATTGCTCGTTTACCGTA -BHQ1 } \\
vanB probe: & TGATTGTCGGCGAAGTGGAT & GCGTGGATAGCGGCTGTA \\
\hline
\end{tabular}

Real Time PCR optimization: Denature: $95^{\circ} \mathrm{C}$ for $15 \mathrm{~s}$, Annealing: $55^{\circ} \mathrm{C}$ for $15 \mathrm{~s}$, Extension: $72{ }^{\circ} \mathrm{C}$ for 1 min, 35 cycles.

Real Time PCR condition: $10 \mu \mathrm{L}$ Real Time PCR master Mix, 2.5 pmol of each primer, 1.5 pmol of each probe, $5 \mu \mathrm{L}$ template, Final volume $23 \mu \mathrm{L}$. 
medical community (Feizabadi et al., 2008, Japoni et al., 2009, Sharifi et al., 2012, Mirzaei et al., 2013) Current study reconfirmed previously published studies. After performing Taq Man Real Time PCR, three strains of Enterococcus faecium and five strains of Enterococcus faecalis were both vanA and vanB positive. According to the Wood ford (1997) during hospital outbreak of VREs, two vanA glycopeptides resistances Enterococcus faecium were isolated with plasmid mediated $v a n B$ resistance. Both were found to be identical to the $\operatorname{van} B$ outbreak strain by pulsed field gel electrophoresis (PFGE). The genotype of this strain changed from $v a n B$ to van $A$ through an intermediate isolate that contained both the van $A$ and $v a n B$ genes clusters on distinct plasmids. In our study by using Taq Man Real Time PCR both vanA and vanB genes were detected too (Wood ford et al., 1997). Michel (2001) reported that gene transferring in bacteria has an important role for the dissemination of resistance genes. Although primarily vanA cluster (in TN1546 and TN5482) was identified in Enterococcus faecium also this cluster has been detected in Enterococcus faecalis. VanB gene cluster exist in TN1546 and has been identified in Enterococcus faecalis and Enterococcus faecium strains. Instability in Enterococci genome and transduction process or up and down regulation of genes probably can be considered as main reasons (Michel et al., 2001, Van den Braak et al., 2000). According to the previously published study by Japoni (2009) vanA gene was detected as predominant determinant in VREs. Also, all of the isolates showed high level resistance to vancomycin itself (Japoni et al., 2009). In this study, in addition to high levels of resistance to vancomycin, in eight of the samples both genes as the main determinants for resistance to vancomycin were observed. Due to the high sensitivity the utilized method in the current study, present of both associate indicators to resistance in some VREs are predictable. However, in most cases, only one of the genes for resistance is adequate (Malathum et al., 2005).

The current study has shown; Taq Man Real Time PCR assay is the useful, precise and rapid method for detection of vancomycin resistance genes in the clinical microbiology laboratory. Although biochemical methods such as E-testing technology for the detection of antibiotics resistance could be more economically efficient, but given the time needed to identify the resistance, using molecular methods such as Taq Man Real Time assay can make a substantial contribution to save a patient's life.

\section{Acknowledgments}

This research financially was supported by Qazvin University of Medical Science.

\section{References}

Arbour N, Weirich A (2008) Real Time detection for VREs. Spartan Bioscience Company 1:1-3.
Clinical and Laboratory Standards Institute (2010) Methods for antimicrobial dilution and disk susceptibility testing of infrequently isolated or fastidious bacteria; approved guideline. M100-S20. Clinical and Laboratory Standards Institute, Wayne, Testing January 30, (20).

Emaneini M, Aligholi M, Aminshahi M (2008) Characterization of glycopeptides, aminoglycosides and macrolides resistance among $E$. faecalis and $E$.faecium isolates from hospital in terhran. Polish J Microbe 57:173-178.

Feizabadi M, Sara Sayadi L, Shokrzadeh MP et al. (2008) Increase in prevalence of vancomycin resistant isolates of E.faecium at Labbafinejad Hospital. Iranian J Clinic Infect Dis 3:73-77.

Forbes BA, Sahmm DF, Weisfeld A (1998) Catalase negative gram positive enterococci. Baily \& Scott Diagnostic Microbiology. $10^{\text {th }}$ ed. Mosby Inc, St Louis, pp 620-635.

Giridhara PM, Upadhya YA, Ravikumar KL et al. (2009) Review of virulence factors of Enterococcus: an emerging Nosocomial Pathogen 27:301-305.

Japoni A, Farshad S, Ziyaeyan M et al. (2009) Detection of van-positive \& negative Vancomycin Resistant enterococci and their antibacterial susceptibility to the newly introduced antibiotics. Pak J Biol Sci 12:844-851.

Kacmaz B, Aksoy A (2005) Antimicrobial resistance of Enterococci in Turkey. Int Antimicrob Agents 25:535-538.

Louis B (2001) Emergence of vancomycin-resistant enterococci. $4^{\text {th }}$ Decennial International Conference on Nosocomial and Healthcare-Associated Infections 7: 183-187.

Laupland KB, Bags haw SM, Greg son DB et al. (2005) Intensive Care Unit-Acquired Tract Infection in a regional critical care system. Critical Care 9:60-65.

Malathum K, Murray BE (1999) Vancomycin-resistant Enterococci: recent advances in genetics epidemiology and therapeutic options drug resistance updates pp 224-243.

Michel A, Richard Q (2001) Regulation of vanA and vanB type glycopeptides resistance in Enterococci. ACC 45:375-87.

Mirzaei B, Naserpoor FT, Jouhari P et al. (2013) Prevalence of vanA and vanB genotypes in vancomycin resistant Enterococcus faecalis and Enterococcus faecium isolated strains by Taq Man Real time PCR assay. JMID 3:192-198.

Pangallo D, Drahovska H, Harichova J (2008) Assessment of environmental Enterococci bacterial antagonism, Pathogenic capacity and antibiotic resistance. Antonie van leeuwenhoek 94:555-562.

Palladino S (2006) Real Time PCR for the rapid detection of vanA and vanB genes. Diag Mic Infect Dis 45:81-84.

Patel R) 1997) Multiplex PCR detection of vanA, vanB, vanC, 1 , and vanC, 2/3 genes in Enterococci. J Clin Microbiol 35:703-707.

Sharifi Y, Hasani A, Ghotaslou R) 2012(Survey of virulence determinants among vancomycin resistant Enterococcus faecalis and Enterococcus faecium isolated from clinical specimens of hospitalized patients of North West of Iran. Open Micro J 6:34-43.

SalemBekhit MM, Moussa IM, Muharram MM) 2012(Prevalence and antimicrobial resistance pattern of multidrug-resistant Enterococci isolated from clinical specimens. Ind J Med Microbiol 30:44-51.

Van den Braak N, Ott A, vanbelkum, A) 2000) Prevalence and determinants of fecal colonization with Vancomycin resistant 
Enterococci in Hospitalized patients in Nederland. Infec Cont Hos Epid 21:520-524.

Wood Ford N, Chadwick PR, Morrison D et al. (1997) Resistant strain of Enterococci faecium can alter their van genotype during outbreak. J Clin Microbiol 35:2966-2968.
Xiomara P, Mendez S (2002) Low prevalence of Vancomycin resistant Enterococci in clinical samples from hospitalized patients of the Canary Islands Spai Int Microb 5:117-120.

Associate Editor: Roxane Maria Fontes Piazza

All the content of the journal, except where otherwise noted, is licensed under a Creative Commons License CC BY-NC. 